\title{
KEBIJAKAN PENGEMBANGAN KURIKULUM PENDIDIKAN ISLAM (Studi Histori dan Regulasi di Indonesia)
}

\author{
Mufarrihul Hazin, Nur Wedia Devi Rahmawati \\ STAI Ma'had Aly Al-Hikam Malang, UIN Syarif Hidayatullah Jakarta, Indonesia
}

Corresponding author: mufarrihulhazin@gmail.com

Submission Track:

$\begin{array}{ll}\text { Submisson } & : 19-07-2021 \\ \text { Accept Submission } & : \text { 19-07-2021 } \\ \text { Avaliable Online } & : 11-09-2021\end{array}$

Copyright @ 2021 Author

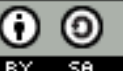

This work is licensed under a Creative Commons Attribution-ShareAlike 4.0

\begin{abstract}
The curriculum becomes an important component in education. Therefore, the development of curriculum in Islamic education is an inevitability, because change must happen with the times. Therefore, the purpose of this writing will be to review the policy of developing of islamic education curriculum, especially in Indonesia by taking into history and regulations. This article uses library research method with content analysis approach. The results showed that the Curriculum Development of Islamic Education in the historical review from the independence period to the reform era continues to change according to the conditions and needs. The development of Islamic education curriculum is divided into 3 periods; i.e. first, the old order period, there were 3 changes, namely the curriculum in 1947, 1952, and the curriculum in 1964; second, the new order period, there were 4 changes, the curriculum 1968, 1975, 1984, and curriculum 1994; third, the reform period, there have been 3 changes, the 2004 curriculum (KBK), curriculum 2006 (KTSP), curriculum 2013 used until now. While in the review of islamic education curriculum regulation there are 4 categories, first, the regulation of madrasah curriculum follows Law Number 20 of 2003 about national education system; second, the regulation of pesantren curriculum follows Law Number 18 of 2019 about Pesantren; third, the regulation of islamic religious college curriculum induces Law Number 12 of 2012 about higher education; and fourth, the regulation of Islamic religious education curriculum for schools / public campuses induces Law Number 20 of 2003 about natioal education system.
\end{abstract}


Keywords: Policy, Curriculum Development, Islamic Education

\begin{abstract}
Abstrak
Kurikulum merupakan komponen terpenting dalam pendidikan. Pengembangan kurikulum dalam pendidikan Islam merupakan sebuah keniscayaan, karena perubahan pasti terjadi mengikuti zamannya. Maka tujuan penulisan ini akan mengkaji terkait kebijakan pengembangan kurikulum pendidikan Islam khususnya di Indonesia dengan memperhatikan sejarah dan regulasi yang berlaku. Tulisan ini menggunakan metode library research dengan pendekatan content analysis. Hasil penelitian menunjukan bahwa kurikulum pendidikan Islam dalam tinjauan sejarah dari masa kemerdekaan hingga era reformasi terus mengalami perubahan sesuai dengan kondisi dan kebutuhan. Pengembangan kurikulum pendidikan Islam terbagi atas 3 masa; yaitu pertama, masa orde lama, terjadi 3 kali perubahan yaitu kurikulum tahun 1947, 1952, dan kurikulum 1964; kedua, masa orde baru, terjadi 4 kali perubahan yaitu kurikulum 1968, 1975, 1984, dan Kurikulum 1994; ketiga, masa reformasi, tejadi 3 kali perubahan yaitu kurikulum 2004 (KBK), Kurikulum 2006 (KTSP), kurikulum 2013 yang dipakai hingga kini. Sedangkan dalam tinjauan regulasi kurikulum pendidikan islam terdapat 4 kategori yakni: pertama, regulasi kurikulum madrasah mengikuti UU nomor 20 tahun 2003 tentang sistem pendidikan nasional; kedua, regulasi kurikulum pesantren mengikuti UU nomor 18 tahun 2019 tentang Pesantren; ketiga, regulasi kurikulum perguruan tinggi keagamaan Islam menginduk UU nomor 12 tahun 2012 tentang pendidikan tinggi; dan keempat, regulasi kurikulum pendidikan agama Islam untuk sekolah/kampus umum menginduk UU nomor 20 tahun 2003.
\end{abstract}

Keywords: Kebijakan, Pengembangan Kurikulum, Pendidikan Islam

\title{
A. PENDAhUluAN
}

Pendidikan Islam dituntut untuk mampu meningkatkan pemahaman ilmu agama dan mengamalkan ajaran Islam. Maka menjadi pendidikan manusia seutuhnya, hati dengan akalnya, jasmani dengan rohaninya, akhlak dan keterampilannya itulah pendidikan Islam (Azyumardi, 1991). Landasan utama untuk pendidikan Islam adalah kitab suci Al-Qur'an dan Al-Hadits (Haidar, 2019). Disamping itu, menurut Abudin Nata (2004) pendidikan Islam di Indonesia harus mampu menjadi suplemen dan komplemen untuk pendidikan nasional. Dengan begitu maka sistem pendidikan nasional mampu menjadikan bangsa Indonesia bangsa yang modern dengan berwajah iman dan takwa sebagai cita-cita nasional.

Relevansi rumusan antara tujuan pembelajaran Islam dengan rumusan tujuan pembelajaran nasional ialah sangat relevan (Ahyar, 2018). Rumusan tentang tujuan pendidikan nasional dalam Sisdiknas (2003) ialah "mencerdaskan kehidupan bangsa serta meningkatkan pribadi individu yang ada menjadi manusia sempurna dan seutuhnya. Maksudanya adalah masnusia yang beriman dan bertaqwa kepada Tuhan YME, memiliki budi pekerti luhur, mempunyai keterampilan dan pengetahuan, fisik yang sehat dan sehat rohani, kepribadian yang mantap, mandiri dan bertanggungjawab terhadap masyarakat dan bangsa Indonesia". 
Kurikulum dalam pandangan Nana S. Sukmadinata (2012) merupakan sebuah rencana pendidikan yang terdiri atas pengalaman dari proses pembelajaran dan disiapkan pihak sekolah untuk peserta didik. Kurikulum menjadi sesuatu yang berarti dalam dunia pendidikan, bahkan tujuan/nawacita pendidikan tidak akan dapat tercapai tanpa kurikulum yang baik dan terstruktur (Ifham, 2019). Kurikulum memiliki fungsi sebagai acuan pelaksanaan kegiatan pendidikan di sekolah atau kampus.

Kurikulum yang berasal dalam Bahasa Yunani dari kata "curir" yang artinya pelari dan kata "curere" artinya tempat berpacu/acuan. Sedangkan Curriculum diartikan sebagai jarak/pedoman yang harus ditempuh oleh seorang pelari tertentu (Anwar dan Mulyani, 2018). Pada saat itu, "kurikulum sebagai sejumlah mata pelajaran yang wajib ditempuh murid guna memperoleh ijazah" (Arief, 2002). Selain itu, menurut Nasution (1995) menyebutkan bahwa kata kurikulum itu berasal dari bahasa Prancis courier yang berarti berlari. Sedangkan kurikulum dalam bahasa Arab disebut dengan istilah manhaj yang artinya jalan/thoriqoh yang terang (Marzuki, 2018). Adapun menurut istilah kurikulum merupakan rancangan pengajaran/pembelajaran yang berisi beberapa mata pelajaran dan disusun secara sistematis berdasarkan kebutuhan peserta didik sebagai persyaratan untuk menyelesaikan program pendidikan (Mastuki \& Hasanah, 2011). Tentunya kurikulum juga bukan sekedar memuat beberapa mata pelajaran saja, namun didalamnya terdapat segala upaya sekolah di dalam sekolah maupun di luar sekolah demi tercapainya tujuan yang diharapkan (Hidayat, 2020). Dalam Undang-Undang Sisdiknas Nomor 20 tahun 2003 menjelaskan bahwa "kurikulum adalah seperangkat rencana dan pengaturan mengenai tujuan, isi, dan bahan ajar, serta cara yang digunakan sebagai pedoman bagi guru dalam menyelenggarakan kegiatan pembelajaran untuk mencapai tujuan tertentu".

Pendidikan Islam adalah suatu upaya terstruktur yang dilakukan melalui lembaga pendidikan Islam dengan materi pendidikan Islam dalam mewujudkan akhlaqul karimah dan berkarakter muslim sehingga apa yang menjadi cita-cita dari masyarakat Islami mampu terwujud (Zulkifli, 2018). Dengan demikian, menurut Noorzanah (2017) kurikulum pendidikan Islam merupakan serangkaian kegiatan yang memuat berbagai macam rencana agenda siswa secara detail yang mencakup materi/isi pendidikan, sarana pembelajaran, strategi dan model belajar, mengajar dan hal-hal lain yang mencakup kegiatan guna mencapai tujuan yang diinginkan berdasarkan ajaran Islam. Kurikulum pendidikan Islam memiliki tujuan untuk menanamkan kepercayaan dalam hati dan pikiran, pemulihan akhlak dan membangun jiwa spiritual generasi muda.

Dengan perkembangan zaman yang semakin hari semakin pesat dan mengingat bahwa posisi kurikulum sangat memiliki pengaruh signifikan terhadap kualitas pendidikan di Indonesia. Maka dengan berbagai rasionalisasi serta alasan, kurikulum di Indonesia terus menerus mengalami perbaikan dan pengembangan dari masa ke masa (Alhamuddin, 2014). Namun inti kurikulum pendidikan Islam, isi materi belajar wajib mencerminkan idealitas Al-Qur'an yang tanpa pilih ataupun memilah disiplin ilmu. Kesempurnaan ajaran agama akan tercapai apabila mampu menserasikan antara ilmu pengetahuan yang dimiliki dengan ilmu agama (Abudin Nata \& Fauzan, 2005). 
Dalam sepanjang sejarah kurikulum sejak tahun 1945 zaman kemerdekaan hingga sekarang, kurikulum pendidikan nasional mengalami perubahan beberapa kali antara lain pada tahun 1947, 1952, 1964, 1968, 1975, 1984, 1994, 2004 (KBK), 2006 (KTSP), dan sampai sekarang yang digunakan adalah kurikulum K-2013 (Alhamuddin, 2014, Abdullah, 2007) Dengan melihat sejarah dari tahun ke tahun setiap perubahan pengembangan kurikulum masih dipengaruhi kuat oleh paradigma politik, dan kekuasaan yang menyelimuti sistem pendidikan Indonesia. Mengingat pentingnya memahami kebijakan pengembangan/ pembaharuan kurikulum pendidikan Islam yang ada di Indonesia, maka dalam tulisan ini akan dibahas tentang kebijakan pengembangan kurikulum yang ditinjau dari studi histori dan regulasi kurikulum pendidikan Islam di Indonesia.

\section{B. KAJIAN PUSTAKA}

\section{Studi Kebijakan Pendidikan}

Kebijakan pendidikan merupakan salah satu disiplin ilmu dari kebijakan publik. Sedangkan kebijakan publik adalah suatu ilmu multi disiplin karena melibatkan berbagai disiplin ilmu seperti ilmu politik, sosial, ekonomi, pendidikan dan psikologi. Begitu juga kebijakan pendidikan, yang merupakan menyangkut hajat orang banyak bukan hanya sekedar kajian sederhana, namun juga merupakan kajian yang sangat komplek. Maka kajian kebijakan pendidikan ini akan dimulai dari mengkaji tentang kebijakan publik.

Kebijakan menurut Anderson (Subarsono, 2005) "kebijakan publik merupakan kebijakan yang ditetapkan oleh badan-badan dan aparat pemerintah". Pendapat yang sama disamaikan oleh Laswell, dkk (Subarsono, 2005) mendefinisikan "kebijakan publik adalah pengalokasian nilai-nilai kepada masyarakat, karena setiap kebijakan mengandung seperangkat nilai di dalamnya". Berdasarkan pendapat diatas, dapat diambil kesimpulan terkait kebijakan itu harus menyentuh value (nilai) yang ada di dalam masyarakat. Dengan demikian jika kebijakan itu berlawanan dengan nilai, tidak dapat digunakan di masyarakat.

Demikian adalah pengertian tentang kebijakan publik. Kemudian saat ini bagaimana hubungannya dengan kebijakan pendidikan. Kebijakan pendidikan konsepnya tidak jauh dengan konsep kebijakan publik, namun hanya lebih spesifik yaitu pada bidang pendidikan. Menurut Good (Hazin, 2017) kebijakan pendidikan yaitu suatu pertimbangan (judgement) yang didasarkan atas nilai dan penilaian terhadap faktor-faktor yang bersifat situasional, pertimbangan tersebut digunakan untuk mengelola dan mengoprasionalkan pendidikan yang bersifat melembaga, hal ini dimaksudkan agar tujuan pendidikan dapat tercapai secara optimal.

Kebijakan pendidikan, sekali lagi tidak bisa lepas dari kebijakan publik, maka ketika belajar kebijakan publik yang menjadikan kebijakan itu sebagai sistem, maka demikian pula kebijakan pendidikan. Jika kebijakan dapat dipandang sebagai suatu sistem, maka kebijakan juga dapat dipandang sebagai 
proses. Menurut Anderson (Tilaar dan Nugroho, 2005) proses kebijakan melalui pentahapan sebagaimana gambar B.1.

Gambar B.1. Proses Kebijakan Publik Menurut Anderson

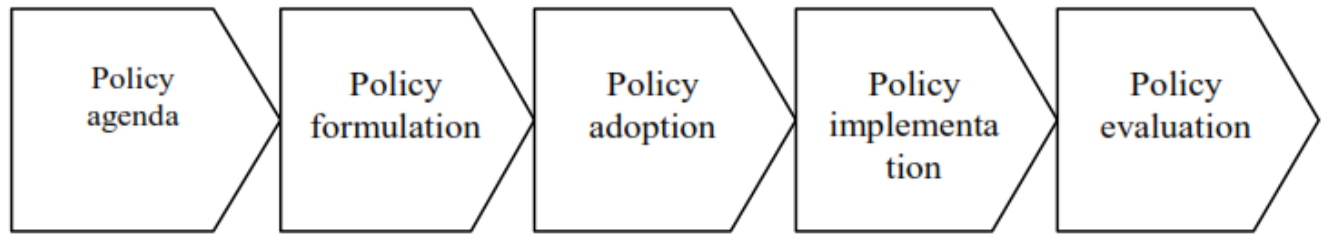

Sumber: Tilaar dan Nugroho, 2005

Pakar yang lainnya, yaitu Dye mengatakan bahwa dalam proses kebijakan memiliki beberapa tahap yang hampir sama dengan model Anderson tersebut. Menurut Dye (Tilaar \& Nugroho, 2008) proses kebijakan publik adalah sebagai berikut

Gambar B.2. Proses Kebijakan Publik Menurut Dye

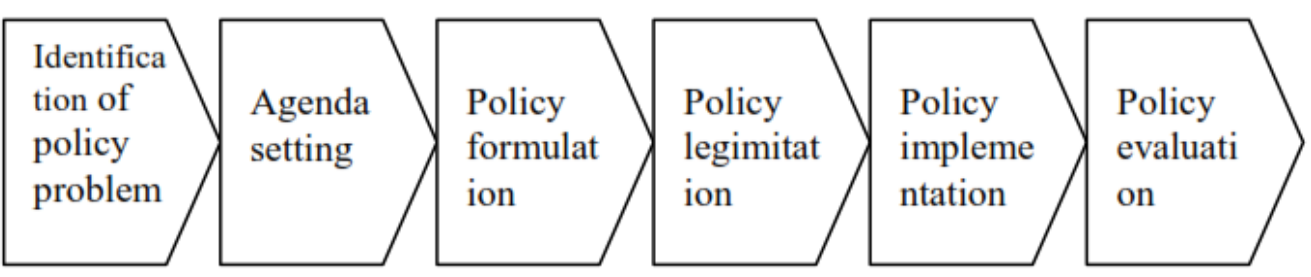

Sumber: Tilaar dan Nugroho, 2008

Berdasarkan kedua konsep/ model proses kebijakan diatas, menunjukan bahwa pentahapan kebijakan model Anderson ditambahi satu pentahapan sebalaum adanya agenda setting yaitu adanya identifikasi permasalah kebijakan (identification of policy problem). Selain itu kalua kita cermati lagi, pendapat Dye mengganti tahapan policy adoption dengan tahapan policy legitimation. Walaupun demikian, hal ini tidak memiliki perbedaan yang siginifikan, mereka hanya menggunakan bahasa yang berbeda. Maknanya mereka memiliki sikap yang sama yaitu menginginkan adanya legitimasi sebagai kebijakan yang sah untuk diambil pemerintah.

Dengan demikian, dari model proses kebijakan publik kita dapat simpulkan terdapat tiga hal paling penting dalam proses kebijakan yakni formulasi, implementasi, dan evaluasi. Begitu halnya juga dalam kebijakan pendidikan, terutamanya dalam kebijakan kurikulum yang terjadi di Indonesia. Proses perkembangan dan perubahan kurikulum pendidikan islam yang ada di Indonesia juga pastinya mengikuti proses kebijakan, yaitu di formulasikan yang diambil dari 
berbagai identifikasi masalah, kemudian disepakati dan menjadi sebuah regulasi, setelah itu kemudian diimplementasikan di lapangan, mulai dari tingkat makro (nasional/daerah), hingga tingkat mikro (satuan pendidikan).

\section{Studi Pengembangan Kurikulum}

Komponen paling penting dalam pendidikan salah satunya adalah kurikulum. Kurikulum merupakan menu program yang disediakan bagi siswa. Sebagaimana yang dijelaskan oleh Hamalik (2012) "Pengembangan kurikulum merupakan suatu proses yang menyeluruh sebagai bentuk kebijakan nasional dalam pendidikan yang disesuaikan dengan visi, misi dan strategi yang dimiliki dari pendidikan nasional". Hal ini yang menjadikan bahwa kurikulum itu sangat penting dan dalam proses pengembangannya dapat mulai dari perencanaan, pelaksanaan, monitoring.

Ketika pengembangan kurikulum yang dimaknai sebagai suatu proses, maka dalam pelaksanaan pengembangannya harus melalui langkah-langkah yang sistematis. Sebagaimana yang digambarkan oleh Hasan (Muhaimin, 2012) dalam gambar berikut ini.

Gambar B.3 Proses Pengembangan Kurikulum

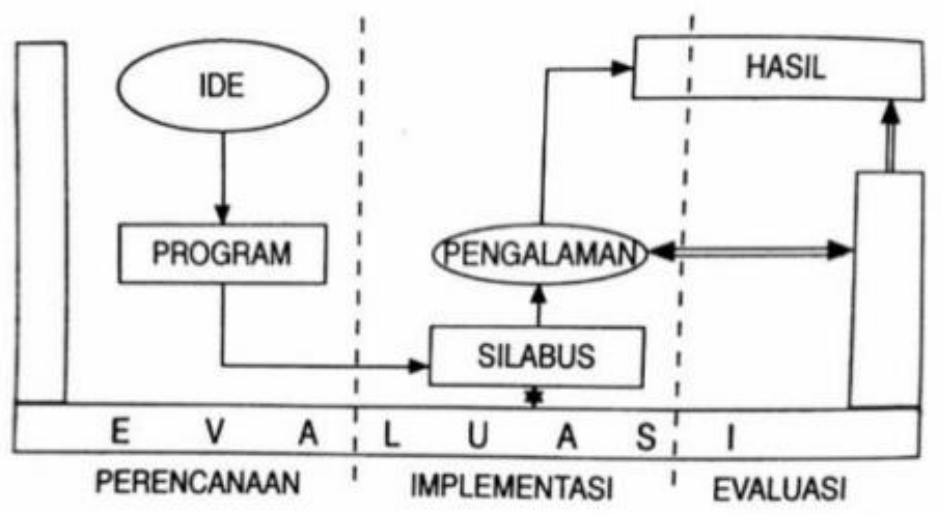

Sumber: Muhaimin, 2012

Proses pengembangan kurikulum pendidikan yang diawali dengan perencanaan kurikulum hingga pada tahap evaluasi. Pada gambar diatas, terlihat bahwa dalam proses perencanaan dimulai dari menentukan atau mencari rumusan ide. Ide dapat berupa dari keadaan perkembangan zaman, visi-misi pemerintah dan yang lainnya. Hasil dari ide itu, lalu dikembangkan dan dituangkan menjadi sebuah program dalam bentuk dokumen. Setelah perencanaan dilakukan, maka kemudian diimplementasikan dalam bentuk pengalaman di lapangan. Untuk mengukur dan emnguji tingkat keefektifan/ pencapaian tujuan pendidikan, maka dibutuhkan adanya evaluasi kurikulum. Hasil evaluasi ini akan diperoleh bekal untuk menyempurnakan kurikulum berikutnya (Fajri, 2019). 
Pengembangan kurikulum pendidikan Islam perlu memperhatikan hal-hal yang mendasar antara lain: Pertama, pengembangan kurikulum dengan menggunakan pendekatan/model keagamaan melalui semua pelajaran dan semua kegiatan. Kedua, penyusunan dalam kurikulum disesuaikan dengan taraf dan standar perkembangan pemahaman dan kemampuan para peserta didik. Ketiga, dalam penyusunan harus berlandaskan prinsip kesinambungan/keberlanjutan, terintegrasi dan sistematis (Tafsir, 1994). Menurut Choli (2019) Pengembangan kurikulum dilakukan secara berjenjang, hal ini mengacu pada pola pikir manajemen, antara lain berdasarkan tingkat makro, tingkat struktural, tingkat mikro, tingkat individual.

Pengembangan kurikulum merupakan sebuah dinamika yang mampu merespon tuntutan perubahan struktural pemerintahan, perkembangan dalam hal ilmu pengetahuan dan teknologi serta globalisasi yang terjadi dan sangat dipengaruhi oleh sumber daya pendukung yakni sumber daya manusia (Alhamuddin, 2014). Pengembangan kurikulum diformulasikan berdasarkan dua bagian penting, Pertama, melihat berdasarkan perkembangan atas kebutuhan, tuntutan, dan kondisi yang terjadi di masyarakat saat itu. Kedua, harus berdasarkan pemikiran dan ide yang mempunyai arah pencapaian pada nilai filosofis (Maarif, 2018). Adapun yang paling utama dan inti dari pengembangan kurikulum berdasarkan sudut pandang islam ialah kebenaran yang bersifat universal dan fundamental dan tidak dapat diubah adalah tauhid (Bilgrami \& Asyraf, 1989). Beberapa unsur yang harus terlihat dalam kurikulum pendidikan Islam antara lain ketauhidan (aqidah), keagamaan (syariah), pengembangan hubungan antar manusia, pengembangan potensi manusia, serta pengembangan diri sebagai individu (Jalaludin \& Idi, 2002).

\section{METODE}

Dalam penelitian yang penulis lakukan, metode yang digunakan adalah library research. Penelitian ini menggunakan sumber data berupa jurnal-jurnal ilmiah, bukubuku dan sumber bacaan lain, baik cetak maupun online bahkan dalam penelitian ini banyak menggunakan perangkan online, sehingga metode ini juga menggunakan model e-research. Adapun jenis penelitian ini merupakan jenis deskriptif-analitik yang dibahas dengan jelas, runtun, dan sistematis.

Teknik pengumpulan data Pustaka melalui membaca dan mencatat bahan penelitiannya. Sehingga peneliti menggunakan model content analysis atau "kajian isi". Data yang dikumpulkan oleh peneliti disini meliputi data sejarah/historis perkembangan kurikulum pendidikan Islam sejak kemerdekaan hingga masa sekarang. Selain itu data yang dikumpulkan juga berupa regulasi/peraturan-peraturan yang digunakan dalam pengembangan kurikulum di Indonesia. Setelah data didapatkan, maka tahap berikutnya yaitu menganalisis. Analisis yang dilakukan yaitu penyajian data dan pembahasan dilakukan secara kualitatif konseptual. 


\section{HASIL DAN PEMBAHASAN}

\section{Studi Histori Kurikulum Pendidikan Islam}

Pengembangan kurikulum pendidikan Islam di Indonesia memiliki sejarah yang panjang. Kurikulum telah mengalami beberapa perubahan yang tentunya berbeda waktu dan kondisi yang dialami. Kurikulum dijadikan sebagai pedoman pendidikan yang harus direncanakan dan diimplementasikan guna mencapai tujuan dari pendidikan. Selain itu, menyiapkan lulusan yang mempunyai jiwa dan karakter yang utuh merupakan fokus dari kurikulum pendidikan Islam. Kurikulum ini secara adaptif diorientasikan untuk merespon dan melawan dekadensi moral, rendahnya pengetahuan dan kemampuan serta kemerosotan moral yang terjadi (Choli, 2019). Kurikulum pendidikan Islam memiliki visi dan misi untuk menterjemahkan pesan kitab suci al-Qur'an dan Al-Hadits guna untuk memperbaiki kualitas kehidupan manusia kearah yang lebih baik. Penulis mencoba menguraikan secara singkat terkait dengan sejarah kurikulum pendidikan Islam yang ada di Indonesia sejak dari masa pasca kemerdekaan sampai saat ini antara lain sebagai berikut:

a. Kurikulum Pendidikan Islam Masa Orde Lama

Penerapan kurikulum pada masa orde lama ini terbagi menjadi dua yakni kurikulum tahun 1947 dan kurikulum tahun 1952 hingga tahun 1964. Mempunyai ciri khas seperti corak dari pendidikan jaman Jepang atau pun jaman Belanda ini terdapat dalam kurikulum 1947 (Dhaifi, 2017, Alhamuddin, 2014). Sedangkan kurikulum tahun 1952 dalam pelaksanaan pembelajarannya, kurikulum ini diatur melalui Undang Undang Nomor 4 Tahun 1950 tentang Pokok Pendidikan dan Pengajaran. Hal ini berlaku hingga adanya SKB 2 menteri yang menyebutkan bahwa pendidikan agama Islam wajib dilaksanakan di satuan pendidikan minimal 2 jam dalam se-minggu.

Departemen Agama RI menurut Mawardi (2016) pada masa orde lama ini mengupayakan adanya kurikulum agama Islam di sekolah-sekolah maupun juga pesantren sehingga dibentuklah tim pengembangan kurikulum agama dengan menunjuk KH. Imam Zarkasyi berasal dari Gontor sebagai ketua dan tim tersebut berhasil menyusun kurikulum agama serta disahkan pada tahun 1952 oleh Menteri Agama RI. Pendidikan agama mendapatkan jatah 25\% dari semua mata pelajaran dalam seminggu di sekolah. Hal ini didapatkan setelah Departemen Agama berhasil menyusun kurikulum itu (Dhaifi, 2017). Dalam pandangan Nasir (2017) madrasah lebih banyak menekankan pada ilmu agama sebagai materi Pendidikan dan ilmu umum hanya mendapat porsi sedikit, dan pada masa ini madrasah hanya hanya ada di lingkup Departemen Agama Republik Indonesia.

\section{b. Kurikulum Pendidikan Islam pada Masa Orde Baru}

Pada masa orde lama mengalami peralihan kurikulum ke kurikulum masa orde baru yang membawa dampak dan mempengaruhi wajah pendidikan nasional. Pada masa orde baru yang merupakan peralihan dari kurikulum orde lama ini terjadi beberapa perubahan kurikulum. Masa orde baru ini mampu 
menyatukan dari berbagai kurikulum Pendidikan Agama Islam sejak 1968, tahun 1975, berubah tahun 1984, menjadi 1994 dan suplemen kurikulum 1999 yang akhirnya berubah menjadi satu paket dengan sistem pendidikan nasional yang ada (Dhaifi, 2017). Kurikulum 1968 ialah penyempurna dari kurikulum 1964 dengan model kurikulum yang terintegrasi dan sistematis. Pada kurikulum 1975, pembelajaran pada Pendidikan agama Islam dalam kurikulum 1975 hadapi pergantian yang sangat lumayan signifikan, yaitu terdapatnya Surat Keputusan Bersama yang disebut dengan SKB tiga menteri (Menteri Agama, Menteri Pendidikan dan Kebudayaan serta Menteri dalam Negeri) dan disusunnya tentang kurikulum madrasah tahun 1975, pembelajaran Pendidikan agama memperoleh jatah $30 \%$, sedangkan untuk pembelajaran umum $70 \%$. Sehingga lulusan dengan ijazah madrasah diakui setingkat dengan lulusan dari sekolah umum, serta para siswa madrasah dapat melakukan pengajuan pindak ke sekolah umum.

Kondisi yang berbeda juga dialami saat kurikulum yang digunakan sebelum kurikulum 1975. Sedangkan kurikulum 1984 menyempurnakan kurikulum 1975. Model kurikulum ini CBSA atau Cara Belajar Siswa Aktif atau dikenal dengan istilah Student Active Learning (SAL). Penguatan pendidikan agama saat itu yaitu dengan adanya SKB Menteri P\&K dan Menteri Dalam Negeri atau yang sering dikenal dengan SKB 2 (dua) Menteri. Isinya ialah untuk mempertegas bahwa siswa setelah lulus dari madrasah mampu mendapat kesempatan melanjutkan pendidikan ke sekolah atau pun kampus umum.

Pengembangan selanjutnya, yaitu pada kurikulum tahun 1994 yang merupakan perpaduan antara kurikulum sebelumnya yaitu tahun 1984 dan 1975. Pada kurikulum inilah terjadi operesi pada siswa, karena adanya tambahan berat beban belajar siswa, mualai dari inti kurikulum nasional hingga mutan lokal kedaerahan. Sehingga, kurikulum 1994 menjelma jadi kurikulum berat dan padat. Beban belajar sisswa menjadi lebih banyak dan semunya harus dituntaskan, dan mereka para siswa tidak dapat memilih untuk menolak seluruh mata pelajar tersebut (Safei \& Hudaidah, 2020).

\section{c. Kurikulum Pendidikan Islam pada Masa Reformasi}

Prinsip mengedepankan transparasi dan keterbukaan yang membawa pengaruh terhadap dunia pendidikan nasional ini ada dalam masa reformasi (Mawardi, 2016). Adanya integrasi pendidikan Islam dalam sistem pendidikan nasional menguatkan keberadaan pendidikan Islam untuk semakin diakui pada masa reformasi ini (Huda \& Rodin, 2020).

Adapun pengembangan kurikulum yang ada di masa reformasi ini antara lain dibuatnya sistem Kurikulum Berbasis Kompetensi (KBK). Memiliki sifat revolusioner dan reformatif dalam kebijakan pendidikan tersebut diperkuat dengan penetapan UU No. 20 tahun 2003 tentang sistem pendidikan nasional (Sisdiknas) yang merupakan pengganti dari UU No. 2 tahun 1989. Dalam proses pembelajaran, pendekatan yang dilakukan adalah Contekstual Teaching and Learning (CTL). Implikasi yang terjadi akibat diterapkannya kurikulum 2004 dan Kurikulum KTSP 2006 terhadap implementasi pendidikan agama Islam di sekolah 
ataupun madrasah. Penjabaran dari kurikulum agama yang dilakukan oleh Kementerian Agama pada bulan Mei 2008 dalam Peraturan Menteri Agama No. 2 Tahun 2008 yang ditandatangani langsung oleh Menteri Agama ini berisi tentang "Standar Kompetensi Lulusan (SKL) dan Standar Isi (SI) dari kurikulum pendidikan agama Islam".

Kurikulum Tingkat Satuan Pendidikan (KTSP) hanya bertahan hingga tahun 2013. Perubahan kurikulum di Indonesia tahun 2013 menjadi K-13. Kurikulum ini memiliki empat aspek penilaian, yaitu aspek pengetahuan, aspek keterampilan, aspek sikap, dan perilaku. Perubahan kurikulum ini, dalam Pendidikan Islam Regulasi kurikulum un akhirnya diganti melalaui No. 165 tahun 2014 tentang pedoman kurikulum madrasah yang akhirnya dirubah lagi dan berlaku hingga saat ini yaitu Keputusan Menteri Agama No.183 tahun 2019 tentang kurikulum PAI dan Bahasa Arab pada madrasah.

Dengan demikian, dari ketiga masa perkembangan kurikulum Pendidikan islam yang ada di Indonesia dapat diambil benang merak sebagai berikut.

Tabel D.1 Ringkasan Histori Perkembangan Kurikulum

\begin{tabular}{|c|c|c|c|c|}
\hline No & Aspek & Masa Orde Baru & Masa Orde Lama & Masa Reformasi \\
\hline 1 & Waktu & $1945-1966$ & 1967-1999 & 1999-Sekarang \\
\hline 2 & $\begin{array}{l}\text { Landasan } \\
\text { Undang- } \\
\text { Undang }\end{array}$ & $\begin{array}{l}\text { UU No. } 4 \text { Tahun } \\
1950 \text { tentang } \\
\text { Pokok Pendidikan } \\
\text { dan Pengajaran. }\end{array}$ & $\begin{array}{l}\text { UU No. } 2 \text { Tahun } \\
1989 \text { tentang } \\
\text { Sistem Pendidikan } \\
\text { Nasional }\end{array}$ & $\begin{array}{l}\text { UU No. } 20 \text { Tahun } \\
2003 \text { tentang Sistem } \\
\text { Pendidikan Nasional }\end{array}$ \\
\hline 3 & $\begin{array}{l}\text { Isi } \\
\text { Kurikulum }\end{array}$ & $\begin{array}{l}\text { Selama Orde } \\
\text { Lama, terjadi } 3 \\
\text { kali pergantian } \\
\text { kurikulum, yaitu: } \\
\text { 1. Kurikulum } \\
1947 \\
\text { 2. Kurikulum } \\
1952 \\
\text { 3. Kurikulum } \\
1964\end{array}$ & $\begin{array}{l}\text { Selama Orde Baru, } \\
\text { kurikulum beganti } \\
\text { hingga } 4 \text { kali, } \\
\text { yaitu: } \\
\text { 1. Kurikulum } \\
1968 \\
2 . \quad \text { Kurikulum } \\
1975 \\
\text { 3. Kurikulum } \\
1984 \\
\text { (CBSA/SAL) } \\
4 . \quad \text { Kurikulum } \\
1994\end{array}$ & $\begin{array}{l}\text { Berganti sebanyak } 3 \\
\text { kali; } \\
\text { 1.Kurikulum } \\
\text { berbasis } \\
\text { Kompetensi (KBK } \\
\text { 2004) } \\
\text { 2.Kurikulum Tingkat } \\
\text { Satuan Pendidikan } \\
\text { (KTSP 2006) } \\
\text { 3.Kurikulum K-13 } \\
\text { (2013) }\end{array}$ \\
\hline
\end{tabular}

Berdasarkan uraian diatas, dapat disimpulkan bahwa kurikulum selalu mengalami perubahan kebijakan dan selalu dikembangkan. Pengemabngan 
kurikulum mengikuti zaman dan kondisi merupakan sebuah keniscayaan yang pasti terjadi. Dalam tinjauan sepanjang sejarah, sejak kemerdekaan hingga saat ini sudah terjadi sepuluh (10) kali perubahan kurikulum. Hal ini tidak menutup kemungkinan dalam waktu dekat atau menangah kedepan pun akan terjadi perubahan kurikulum yang disesuaikan dengan tuntutan zaman.

\section{Studi Regulasi Kurikulum Pendidikan Islam}

Kurikulum pendidikan Islam secara regulasi yang ada di Indonesia sudah lengkap. Mulai dari peraturan perundang-undangan, Peraturan Pemerintah, dan Peraturan Menteri. Di dalam regulasi kurikulum pendidikan Islam tidak bisa lepas dari Sistem Pendidikan Nasional yang tercantum di dalam UU No. 20 Tahun 2003 pada bab X tentang kurikulum Pasal 36 ayat 1 dan 2 "(1) pengembangan kurikulum dilakukan dengan mengacu pada standar nasional pendidikan untuk mewujudkan tujuan pendidikan nasional, (2) kurikulum pada semua jenjang dan jenis pendidikan dikembangkan dengan prinsip diversifikasi sesuai dengan satuan pendidikan, potensi daerah, dan peserta didik."

Berdasarkan UU tersebut, bahwa pengembangan kurikulum harus mengacu pada Standar Nasional Pendidikan (SNP), berlaku juga untuk kurikulum pendidikan Islam. Dari UU tersebut diperjelas dalam Peraturan Pemerintah (PP) No. 17 tahun 2010 pasal 190 ayat 2 Pasal 190 "Satuan pendidikan berbasis masyarakat sebagaimana dimaksud dalam pasal 189 dapat mengembangkan kurikulum sesuai dengan kekhasan agama atau lingkungan sosial dan budaya masing-masing."

Pembahasan kurikulum pendidikan Islam yang terdapat di Indonesia perlu dijabarkan sesuai dengan jenis kelembagaan. Pendidikan Islam di Indonesia terdiri dari pendidikan madrasah, pendidikan pesantren dan diniyah, pendidikan tinggi keagamaan Islam, serta Pendidikan Agama Islam di sekolah dan kampus umum.

a. Kurikulum Madrasah

Madrasah adalah institusi pendidikan Islam di Indonesia yang muncul setelah adanya ide pembaharuan dan pengembangan pemikiran Islam di Indonesia. Berawal dari inisiasi masyarakat Islam yang ingin mendidik siswa untuk mampu memahami, menghayati dan mengamalkan ajaran Islam degan utuh dan baik maka berdirilah madrasah (Jannah, 2013). Setelah itu lahirlah Peraturan Pemerintah Nomor 28 Tahun 1990 pasal 4 ayat 2 tentang "SD, SMP, yang bercirikan Islam dan dikelola oleh Departemen Agama yang disebut dengan madrasah."

Madrasah itu sendiri terdiri dari Madrasah Ibtidaiyah (MI), Madrasah Tsanawiyah (MTs) dan Madrasah Aliyah (MA). Secara keseluruhan struktur kurikulum madrasah baik MI, MTs, maupun MA terdiri atas muatan antara lain pendidikan agama, pendidikan kewarganegaraan, bahasa, matematika, ilmu pengetahuan alam, ilmu pengetahuan sosial, seni dan budaya, pendidikan jasmani dan olahraga, keterampilan/kejuruan, serta muatan lokal. Hal ini 
sesuai dengan Peraturan Menteri Agama (PMA) Nomor 90 tahun 2013 tentang penyelenggaraan pendidikan madrasah.

Madrasah memiliki kurikulum yang disesuaikan dengan Standard Nasional Pendidikan (SNP), sehingga diatur melalui peraturan pemerintah dan dijabarkan dalam Peraturan Menteri Pendidikan dan Kebudayaan (Permendikbud). Untuk struktur kurikulum sekolah/madrasah yang dipakai saat ini menggunakan Permendibud No. 67-70 tahun 2013. Penjabaran khusus kurikulum di madrasah diatur lebih rinci di dalam Keputusan Menteri Agama (KMA) Nomor 183 Tahun 2019 tentang Kurikulum PAI dan bahasa Arab pada madrasah serta KMA No. 184 tahun 2019 tentang Pedoman Implementasi Kurikulum pada madrasah. KMA ini berlaku sejak ajaran tahun 2020/2021 pada seluruh madrasah di Indonesia.

Berdasarkan pada peraturan diatas, mata pelajaran agama yang terdapat pada kurikulum madrasah dibagi menjadi sub-sub mata pelajaran antara lain fiqih, al-Qur'an hadist, akidah akhlak, mata pelajaran sejarah kebudayaan Islam, dan mata pelajaran bahasa Arab yang diterapkan dari madrasah ibtidaiyah hingga aliyah. Melihat hal tersebut, maka mata pelajaran pendidikan agama Islam mendapatkan porsi lebih banyak dari mata pelajaran lain. Sedangkan sekolah non-madrasah atau umum mendapatkan porsi pelajaran Pendidikan agama Islam dua jam perminggu yang didalamnya meliputi alQuran hadits, akidah akhlak, ibadah, syariah, fiqih, dan sejarah kebudayaan Islam (Khoiruddin, 2016).

Saat ini kalau dilihat dari struktur kurikulumnya, madrasah sering mendapatkan kritik dari para pemikir dan praktisi Pendidikan islam, khususnya untuk madrasah modern. Madrasah sering kali disebut setengah hati dalam menerapkan strukturnya. Hal ini disebabkan karena struktur kurikulum madrasah alokasi waktu pelajaran agamanya dikurangi dan mengejar ilmu pengetahuan umum dan teknologi, namun hasilnya tidak ada yang tuntas. Penerapan kurikulum di madrasah ini, mengakibatkan saat siswa madrasah akan melanjutkan ke perguruan tinggi. Ketika akan mengambil jurusan umum, mereka akan kalah dengan lulusan SMA, dan juga ketika akan melanjutkan ke perguruan tinggi agama, mereka para lulusan madrasah kurang bekal dalam mendalami pengetahuan keagamaan dan bahasa Arab. Dengan demikian sebagai solusinya dibuatkan jalur boarding school (sekolah berasrama) agar memiliki waktu belajar penuh selama 24 jam setiap harinya (Mukhlis,2017).

Regulasi pengembangan kurikulum pendidikan Islam khususnya di madrasah terakhir kali dilakukan pengembangan kurikulum yaitu dengan adanya "Keputusan Menteri Agama No.183 tahun 2019 tentang kurikulum PAI dan Bahasa Arab pada madrasah yang merevisi KMA No. 165 tahun 2014 tentang pedoman kurikulum madrasah." Dalam pengembangan kurikulum pada KMA 183 tahun 2019 terdapat penyempurnaan dari kurikulum sebelumnya, diantara adalah pada aspek materi dan proses pembelajaran yang disesuaikan dengan pembelajaran abad 21 . Khusus untuk kurikulum bahasa 
Arab, kurikulum tahun 2019 lebih mengutamakan pada aspek fungsional daripada aspek structural (Amin, 2020).

b. Kurikulum Pesantren

Didirikannya pesantren memiliki tujuan untuk mendalami ilmu-ilmu agama. Menurut Daulay (2019) lembaga pendidikan Islam yang paling tua di Indonesia ini adalah pesantren. Lembaga yang dengan nuansa kesederhanaan sejak dulu bahkan hingga sekarang di jaman modern ini, pesantren tetap dengan ciri khasnya sendiri dibandingkan dengan lembaga pendidikan formal seperti sekolah dan madrasah. Dalam beberapa penelitian terhadap pesantren ditemukan bahwa pesantren mempunyai kewenangan tersendiri dalam menyusun dan mengembangan kurikulumnya (Arifai, 2018).

Kurikulum pesantren, secara tersurat juga telah diatur dalam UndangUndang No 18 Tahun 2019 tentang Pesantren. Pada pasal 16 "Pesantren menyelenggarakan fungsi pendidikan berdasarkan kekhasan, tradisi, dan kurikulum pendidikan masing-masing Pesantren." Dijabarkan lebih lanjut dalam Pasal 18 "(1) Kurikulum Pendidikan Muadalah terdiri atas kurikulum Pesantren dan kurikulum pendidikan umum. (2) Kurikulum Pesantren dikembangkan oleh Pesantren dengan berbasis Kitab Kuning atau Dirasah Islamiah dengan Pola Pendidikan Muallimin".

Undang-Undang Pesantren sejatinya adalah rekognisi (pengakuan) negara terhadap alumni pesantren secara instituti, baik formal atau non formal. Menurut Sanusi (2012) "Pendidikan formal pesantren dalam bentuk pendidikan muadalah (Ula, Wustho, dan Ulya) dan pendidikan diniyah formal, serta Ma'had 'Aly. Adapun jalur pendidikan nonformal berbentuk Kajian kitab kuning dengan model dan metode pembelajarannya. Demikian pula semua lulusan pesantren diakui sama dengan lulusan pendidikan formal pada jenjang tertentu setelah dinyatakan lulus ujian dan lulusannya dapat melanjutkan ke jenjang pendidikan formal yang lebih tinggi, baik yang sejenis maupun tidak sejenis dan/atau kesempatan kerja".

Berdasarkan UU Pesantren tersebut, kurikulum pendidikan islam di pesantren semakin jelas dan mendapat pengakuan negara secara resmi dan dikembangkan berdasarkan kekhasaan dan tradisi masing-masing pesantren. Menurut penelitian Lukens-Bull menyatakan bahawa secara garis besar kurikulum pesantren dapat diklasifikasikan menjadi 4 bagaian, yaitu; Pendidikan Agama Islam, pengalaman dan pendidikan etika, sekolah dan pendidikan pengetahuan umum, serta keterampilan dan kursus (Aly, 2011).

c. Kurikulum Perguruan Tinggi Keagamaan Islam

Kurikulum ini biasa disingkat dengan sebutan kurikulum PTKI. Ajaran Islam memiliki substansi yang sangat luas, baik di bidang aqidah, Syariah serta IPTEK yang modern. Lahan garap keilmuan pada perguruan tinggi Islam ini meliputi aspek kebutuhan hidup manusia untuk kehidupan akhirat yang bahagia merupakan predikat Islam yang sangat melekat. 
Dalam PTKI, kurikulumnya tetap berlandaskan pada Undang-Undang (UU) No. 12 Tahun 2012 tentang Pendidikan Tinggi. Pada paragraf 1 pasal 35 menjelaskan; "(1) Kurikulum pendidikan tinggi merupakan seperangkat rencana dan pengaturan mengenai tujuan, isi, dan bahan ajar serta cara yang digunakan sebagai pedoman penyelenggaraan kegiatan pembelajaran untuk mencapai tujuan Pendidikan Tinggi. (2) Kurikulum Pendidikan Tinggi dikembangkan oleh setiap Perguruan Tinggi dengan mengacu pada Standar Nasional Pendidikan Tinggi untuk setiap Program Studi yang mencakup pengembangan kecerdasan intelektual, akhlak mulia, dan keterampilan. (3) Kurikulum Pendidikan Tinggi wajib memuat mata kuliah: a. agama; b. Pancasila; c. kewarga-negaraan; dan d. bahasa Indonesia. (4) Kurikulum Pendidikan Tinggi dilaksanakan melalui kegiatan kurikuler, kokurikuler, dan ekstrakurikuler."

Proses pengembangan kurikulum dalam perguruan tinggi keagamaan islam (PTKI) setelah adanya perubahan nomenklatur dari STAIN/IAIN menjadi UIN terdapat proses perubahan kurikulum yang sangat drastic. Hal ini disebabkan perubahan nomenklatur ini juga merubah kurikulum yang tidak hanya berorientasi pada pengetahuan agama islam, namun juga dalam skala keilmuan yang lebih luas. Masyarakat membutuhkan kurikulum Pendidikan islam di perguruan tinggi untuk lebih progresif dan dapat menjawab kebutuhan yang terjadi di masyarakat. Hal ini menuntut Lembaga untuk berbenah dalam struktur kurikulum dan model pengajarannya. Menurut Hidayat (2000) Perubahan ini menekankan untuk Perguruan Tinggi Keagamaan Islam harus menjadi lembaga pengembangan ilmu agama Islam, bukan sekedar menjadi pusat doktrin Islam seperti periode sebelumnya. Menurut Na'im (2021) capaian pengembangan yang dilakukan oleh STAIN/IAIN menjadi UIN menjadi gambaran bahwa dalam aspek manajerial lembaga mereka bisa dikatakan sudah baik dan profesional.

Selain persoalan pengembangan kurikulum PTKI pada perubahan nomenklatur menjadi UIN, Namun perkembangan kurikulum berbasis Kerangka Kualifikasi Nasional Indonesia (KKNI). KKNI tersebut digunakan untuk menilai kesetaraan capaian dalam proses pembelajaran serta meningkatkan kualifikasi tenaga kerja baik di dalam atau luar negeri. Menurut Direktorat PTKI (2018) KKNI menjadi sangat penting seiring dengan perkembangan teknologi yang begitu pesat dan pergerakan manusia yang cukup dinamis. Hal ini yang membuat kesepakatan pasar bebas di wilayah Asia Tenggara bahkan di dunia tidak terhindarkan lagi. Kebebasan ini memungkinkan pergerakan tenaga kerja antar negara.

\section{d. Kurikulum PAI}

Amanat UU Sisdiknas 2003 yang tercantum dalam pasal 37 adalah “(1) Kurikulum pendidikan dasar dan menengah wajib memuat: a. pendidikan agama; b. pendidikan kewarganegaraan; c. bahasa; d. matematika; e. ilmu pengetahuan alam; f. ilmu pengetahuan sosial; g. seni dan budaya; $h$. 
pendidikan jasmani dan olahraga; i. keterampilan/ kejuruan; dan j. muatan lokal. (2) Kurikulum pendidikan tinggi wajib memuat: a. pendidikan agama; b. pendidikan kewarganegaraan; dan c. bahasa".

Berdasarkan UU tersebut, pendidikan agama mejadi kurikulum wajib pada seluruh jenjang pendidikan mulai dasar, menengah hingga tinggi. Hal ini merupakan bentuk dari wujud usaha pemerintah dalam upaya memperbaiki pendidikan agama Islam di Indonesia (Jannah, 2013). Untuk implementasinya diperjelas dalam Permendikbud No. 57-60 Tahun 2014 tentang muatan kurikulum Sekolah termasuk di dalamnya kurikulum PAI pada sekolah.

Pendidikan Agama Islam (PAI) di sekolah-sekolah umum saat ini masih jauh dari harapan masyarakat. Hal ini disebabkan dengan banyaknya kendala yang terjadi di lapangan., maka diperlukan pedoman dan acuan untuk pegangan dalam melakukan pembinaan pendidikan agama Islam di sekolah (Yunita, 2016). Regulasi Pendidikan Agama Islam (PAI) saat ini dinilai telah usang. Pembaharuan regulasi menjadi fokus program yang akan segera dilaksanakan oleh Direktorat PAI. Aturan yang dipakai sampai saat ini adalah Keputusan Menteri Agama No 211 Tahun 2011 yang mangatur tentang Pedoman Pengembangan Standar Nasional PAI pada sekolah.

Harapan besar terhadap pengembangan kurikulum PAl di sekolah adalah tentang aspek sikap dan karakter peserta didik. Namun situasi ini yang menjadi sorotan, karena terjadinya merosotan moral dan karakter para generasi muda saat ini. Guru PAl dianggap sebagai orang yang paling bertanggungjawab terhadap moral peserta didik di sekolah. Hal ini lumrah dan biasa tentunya, mengingat isi materi PAl yang kaya akan nilai-nilai luhur yang sempurna dan baik (Hidayat, 2020).

\section{KESIMPULAN}

Kurikulum pendidikan Islam dalam tinjauan sejarah dari masa kemerdekaan hingga era reformasi terus mengalami perubahan sesuai dengan kondisi dan kebutuhan. Pengembangan kurikulum pendidikan Islam terbagi atas 3 masa; yaitu pertama, masa orde lama, terjadi 3 kali perubahan yaitu kurikulum tahun 1947, 1952, dan kurikulum 1964; kedua, masa orde baru, terjadi 4 kali perubahan yaitu kurikulum 1968, 1975, 1984, dan Kurikulum 1994; ketiga, masa reformasi, tejadi 3 kali perubahan yaitu kurikulum 2004 (KBK), Kurikulum 2006 (KTSP), kurikulum 2013 yang dipakai hingga kini. Sedangkan dalam tinjauan regulasi kurikulum pendidikan islam terdapat 4 kategori yakni: pertama, regulasi kurikulum madrasah mengikuti UU nomor 20 tahun 2003; kedua, regulasi kurikulum pesantren mengikuti UU nomor 18 tahun 2019; ketiga, regulasi kurikulum perguruan tinggi keagamaan Islam menginduk UU nomor 12 tahun 2012; dan keempat, regulasi kurikulum pendidikan agama Islam untuk sekolah/kampus umum menginduk UU nomor 20 tahun 2003. 


\section{REFERENSI}

Abdullah, A. (2007). Kurikulum Pendidikan di Indonesia Sepanjang Sejarah. In Pendidikan dan Kebudayaan (p. 343). file:///C:/Users/ACER/Downloads/354Article Text-1134-1-10-20160929.pdf

Alhamuddin. (2014). Sejarah Kurikulum di Indonesia. Nur El-Islam, 1, 48-58.

Aly, A. (2011). Pendidikan Islam Mulltikulturalisme di Pesantren; Telaah Kurikulum Pondok Pesantren Islam Assalam Surakarta. Yogyakarta; Pustaka Pelajar.

Amin, K, (2021). Ini Persamaan dan Penyempurnaan Kurikulum PAl dan Bahasa Arab Madrasah. Diakses melalui https://kemenag.go.id/berita/read/513676/inipersamaan-danpenyempurnaan-kurikulum-pai-dan-bahasa-arab-madrasah diakses 16 Mei 2021 pukul 05.07 WIB.

Anwar, A.S \& Mulyani. N. (2018) Kurikulum Pendidikan Islam Dalam Lintasan Sejarah, Jurnal Genealogi PAl, 5(1), 1-7. http://dx.doi.org/10.32678/geneologipai.v5i1.1037

Arief, A. (2002). Pengantar IImu Dan Metodologi Pendidikan Islam, Cet.1. Jakarta: Ciputat Pers.

Arifai, A. (2018). Pengembangan Kurikulum Pesantren, Madrasah Dan Sekolah. Raudhah Proud To Be Professionals: Jurnal Tarbiyah Islamiyah, 3(2), 13-20. https://doi.org/10.48094/raudhah.v3i2.27

Azra, A. (1999). Pendidikan Islam Tradisi dan Modernisasi Menuju Milenium Baru. Jakarta: Logos Wacana Ilmu.

Bilgrami, H.H \& Asyraf, S.A. (1989). Konsep Universitas Islam. Yogyakarta: PT Tiara Wacana.

Choli, I. (2019) Hakikat Pengembangan Kurikulum Pendidikan Islam, Jurnal Al-Risalah, X(2), 100-127. DOI: https://doi.org/10.34005/alrisalah.v10i2.407

Dhaifi, A. (2017). Perkembangan Kurikulum PAI di Indonesia, Jurnal Edureligia, 1(1), 76-88. DOI: https://doi.org/10.33650/edureligia.v1i2.47

Direktorat PTKI, (2018). Panduan Pengembangan Kurikulum PTKI Mengacu pada KKNI dan SN-Dikti. Tidak diterbitkan.

Fajri, K. N. (2019). Proses Pengembangan Kurikulum. Islamika, 1(2), 35-48. https://doi.org/10.36088/islamika.v1i2.193

Hasbullah. (2015). Kebijakan Pendidikan dalam Perspektif Teori, Aplikasi dan Kondisi Objekif dalam Pendidikan di Indonesia. Jakarta: Raja Grafindo Persada.

Muhaimin. (2012). Pengembangan Kurikulum Pendidikan Agama Islam di Sekolah, Madrasah, dan Perguruan Tinggi. Jakarta: PT RajaGrafindo Persada.

Hazin, M. (2017). Implementation of character education policy at colleges. In Proceeding the International Conference on Education Innovation (Vol. 1, No. 1, pp. 530-535). 
Hidayat, A. W. (2020). Studi Kebijakan Pengembangan Kurikulum Pendidikan Agama Islam Model Kurikulum 2013, Al-Murabbi: Jurnal Studi Kependidikan dan Keis/aman, 6(2), 172-188. https://doi.org/10.53627/jam.v6i2.3792

Hidayat, K. (2000). Problem dan Prospek IAIN; Antologi Pendidikan Tinggi Islam. Jakarta; Departemen Agama RI.

Huda, M \& Rodin, R. (2020). Perkembangan Pendidikan Islam di Indonesia dan Upaya Penguatannya dalam Sistem Pendidikan Nasional, Journal of Islamic Education Research, 1(2), 39-53 https://doi.org/10.35719/jier.v1i02.24

Jalaluddin \& Idi, A. (2002). Filsafat Pendidikan; Manusia, Filsafat, dan Pendidikan, cet.2. Jakarta: Gaya Media Pratama.

Jannah, F. (2013) Pendidikan Islam Dalam Sistem Pendidikan Nasional, Jurnal Dinamika Ilmu, 13(2), https://doi.org/10.21093/di.v13i2.23

Kamal, M. (2014). Model Pengembangan Kurikulum Dan Strategi Pembelajaran Berbasis Sosiologi Kritis, Kreativitas, Dan Mentalitas. Jurnal Madaniyah, VII(9), 230-250.

Khoiruddin, M. (2016). Analisis Kebijakan Kurikulum Pendidikan Islam di Lembaga Pendidikan Islam. JOIES: Journal of Islamic Education Studies, 1(1), 141-154. https://doi.org/10.15642/joies.v1i1.7

Ma'arif, M. A. (2018) Paradigma Baru Pengembangan Kurikulum Pendidikan Agama Islam, Jurnal Pedagogik, 5(1), 109-123 https://doi.org/10.33650/pjp.v5i1.227

Marzuki, B. (2008). FALSAFAH KURIKULUM DALAM PENDIDIKAN ISLAM. HUNAFA: Jurnal Studia Islamika, 5(1),

https://doi.org/https://doi.org/10.24239/jsi.v5i1.149.23-36

Mawardi, A. (2016). Perkembangan Kurikulum Pendidikan Agama Islam di Indonesia, Jurnal Tarbawi, 1(1), 29-36. https://doi.org/10.26618/jtw.v1i1.350

Na'im, Z. (2021). SEJARAH PERKEMBANGAN MANAJEMEN LEMBAGA PENDIDIKAN ISLAM. Evaluasi: Jurnal Manajemen Pendidikan Islam, 5(1), 71-93. http://doi.org/10.32478/evaluasi.v5i1.569

Nasution, S. (1995). Asas-asas Kurikulum, Cet.II. Jakarta: Bumi Aksara.

Nata, A \& Fauzan. (2005). Pendidikan Dalam Perspektif Hadits, Cet.I. Jakarta: UIN Press.

Nata, A. (2004). Tokoh-Tokoh Pembaharuan Pendidikan Islam di Indonesia. Jakarta: Raja Grafindo.

Noorzanah. (2017). Konsep Kurikulum Dalam Pendidikan Islam, Ittihad Jurnal Kopertais Wilayah XI Kalimantan, 15(28), 68-74. http://dx.doi.org/10.18592/ittihad.v15i28.1934

Safei, \& Hudaidah. (2020). Sistem Pendidikan Umum Pada Masa Orde Baru (19681998). Jurnal Humanitas, 7(1), 1-13. https://ejournal.hamzanwadi.ac.id/index.php/jhm/article/view/3253 
Sanusi, U. (2012). Pendidikan Kemandirian di Pondok Pesantren (Studi Mengenai Realitas Kemandirian Santri di Pondok Pesantren al-Istiqlal Cianjur dan Pondok Pesantren Bahrul Ulum Tasikmalaya. Jurnal Pendidikan Agama Islam Ta'lim, 10(2),

Tafsir, A. (1994). Ilmu Pendidikan Dalam Perspektif Islam. Bandung: PT Remaja Rosdakarya.

Yunita, Y. (2016). Pengembangan Kurikulum PAI Di Sekolah Umum. Jurnal Dewantara, 2(02), 162-178.

Zulkifli. (2018). Regulasi Pendidikan Islam, Jurnal Rausyan Fikr, 14(02), 63-74. DOI: http://dx.doi.org/10.31000/rf.v14i02.904

\section{Peraturan-Peraturan}

Undang-Undang No. 20 Tahun 2003 tentang Sistem Pendidikan Nasional.

Undang-Undang No. 12 Tahun 2012 tentang Pendidikan Tinggi.

Undang-Undang No. 18 Tahun 2019 tentang Pesantren.

Peraturan Pemerintah No. 17 tahun 2010 tentang Pengelolaan dan Penyelenggaraan Pendidikan. 